Solohubova, S., Lakhno, O., Shyyan, V., \& Shyyan, O. (2020). The Assessment of Physical Fitness and Morphofunctional State of Female First-Year Students in Non-Linguistic Higher Education Institutions. Teoriâ ta Metodika Fìzičnogo Vihovannâ, 20(3), 157164. https://doi.org/10.17309/tmfv.2020.3.05

ISSN 1993-7989 (print). ISSN 1993-7997 (online)

\title{
THE ASSESSMENT OF PHYSICAL FITNESS AND MORPHOFUNCTIONAL STATE OF FEMALE FIRST-YEAR STUDENTS IN NON-LINGUISTIC HIGHER EDUCATION INSTITUTIONS
}

\author{
Svitlana Solohubova ${ }^{1 \mathrm{ABCDE}}$, Olena Lakhno ${ }^{1 \mathrm{ABCDE}}$, Volodymyr Shyyan ${ }^{1 \mathrm{ABCDE}}$, Olga Shyyan ${ }^{1 \mathrm{ABCDE}}$ \\ ${ }^{1}$ Prydniprovska State Academy of Civil Engineering and Architecture
}

Authors' Contribution: A - Study design; B - Data collection; C - Statistical analysis; D - Manuscript Preparation; E - Funds Collection

Corresponding Author: Svitlana Solohubova, E-mail: sologubova.svitlana@pgasa.dp.ua

Accepted for Publication: September 20, 2020

Published: September 25, 2020

DOI: 10.17309/tmfv.2020.3.05

\begin{abstract}
The purpose of this research paper is to study physical fitness and functional state of female first-year students in Prydniprovska State Academy of Civil Engineering and Architecture.

Materials and methods. The study involved 100 female first-year students of general group aged 17-18, all after medical examination and obtaining doctor's approval: the age group was 18 years old $(\mathrm{n}=100)$. To meet the goals set, the following research methods were used: theoretical analysis and generalization of data in specialized scientific and methodological literature, pedagogical testing, anthropometric research methods, functional methods of cardiorespiratory system investigation and methods of mathematical statistics for processing the results of the research. Results. the conducted study proved the hypothesis on the necessity to improve the system of physical education in technical higher educational institutions, which is connected with the low level of physical fitness among students. Conclusions. The study revealed the low level of physical fitness among the investigated students in terms of speed and strength endurance indicators (with 83\%), explosive physical force of the lower limbs (with 82\%) and strength endurance of the upper limbs (with 68\%), as well as reduced functional characteristics: resistance to hypoxia (according to the results of the Shtange test with $46 \%$ and the Gench test with $49 \%$ ), workability (with $71 \%$ ) and efficiency of cardiovascular system (with 55\%). Low physical fitness levels among the tested girls necessitate the additional introduction of more intensive training. The high variability of the physical fitness indicators among the students requires personalization of the training process, as well as the obligatory use of express testing methods for the physical state of each student during a workout.

Keywords: students, physical education, physical state, functional indicators, physical fitness.
\end{abstract}

\section{Introduction}

Problem statement. When analysing individual physical fitness, some researchers primarily focus on the study of fitness level as one of its fundamental components. Some researchers have ascertained an overall decline in the physical fitness level in societies both in Ukraine (Kashuba, Asauliuk, \& Diachenko, 2019; Bondarenko, Dziuban, Isaienko, \& Bondarenko, 2018) and abroad (Prusik, Prusik, Iermakov, \& Kozina, 2012; Osipov, Vonog, Prokhorova, \& Zhavner, 2016). As the problem of physical activity is becoming increasingly pressing in Ukraine, the measures aimed at improving the physical fitness of the country's population have

(C) Svitlana Solohubova, Olena Lakhno, Volodymyr Shyyan, Olga Shyyan, 2020. been enforced legislatively, namely the requirements for annual fitness assessment of people under 21 years of age in compliance with the Resolution of the Cabinet of Ministers of Ukraine "On approval of annual physical fitness assessment of Ukraine's population" (Resolution No 1045 as of December 9, 2015) and the Order of the Ministry of Education and Science of Ukraine (Order No 4665 as of December 15, 2016). However, in practice such measures do not seem to have led to any significant changes in the physical fitness level of young people (Osipov \& Budnyi, 2017).

Thus, Kashuba et al. (2019), Bondarenko et al. (2018) and Malimon, Pantik, and Tsos (2018) highlight the predominantly low fitness level among students, besides, according to studies by Moskalenko and Pichurin (2017), Osipov and Budnyi (2017) and Zhamardiy, Shkola, Tolchieva, and Saienko (2020), 
the fitness level of girls and young women was lower than the fitness level of boys and young men of the same age.

All that necessitate a more thorough study and analysis dedicated to the issue of physical fitness and functional state among young people in Ukraine.

Analysis of research and publications. Studies of physical fitness and functional state of students is a crucial issue of national importance, which can be evidenced by a large number of publications devoted to this issue. Most experts in both physical education and health care have been making efforts to increase the levels of young people's physical fitness.

The analysis has shown that the main reasons for low physical fitness levels among youth are as follows:

- decline in motor activity of the population related to universal automation and modernization of life (Osipov, Kudryavtsev, Iermakov, Yanova, Lepilina, Plotnikova, \& Dorzhieva, 2017);

- lack of motivation to do sports or work out (Anikieiev, 2015; Jaakkola, Yli-Piipari, Barkoukis, \& Liukkonen, 2017; Sulz, Temple \& Gibbons, 2016);

- lack of a differentiated approach while selecting the load level at physical education classes (Nagovitsyn, Osipov, Manurov, Zhuikov, \& Vershinina, 2019);

- reduction of mandatory hours on physical education in nonspecialized universities and transfer of these classes to an optional or elective form (Kashuba et al., 2019; Gryban, 2014);

- deterioration of ecological environment (Lebedinskiy, Koipysheva, Rybina, Kudryavtsev, Iermakov, Osipov, \& Sidorov, 2017; Paliienko, 2017; Trotska, Homlia, \& Kovalenko, 2018).

The researchers offer a range of measures to increase the youth's fitness levels. Thus, Aghyppo, Tkachov, and Orlenko (2016) recommend promotion of a healthy lifestyle as the main objective of physical education in schools and universities. Gryban (2014) believes that it is possible to change the existing situation by improving the educational process at physical education classes and increasing the quality of education by enhancing teacher's performance. Kozina, Ol'khovyj, and Temchenko (2016) suggest computer technologies as an important component aimed at enhancing the quality and effectiveness of PE classes. Puzdymir (2019) and Vaskevich (2019) offer to prioritize physical training and purposeful development of physical skills as the main component of physical education programme. Butenko, Goncharova, Saienko, and Tolchieva (2017) recommend promoting tourism with the aim of increasing students' interest, and Yarmak, Galan, Hakman, Dotsyuk, and Blagii (2017) and Skurikhina, Kudryavtsev, Kuzmin, and Iermakov (2016) advise including fitness technologies in physical education programme.

Other experts consider it necessary to focus efforts on improving the physical fitness of those categories of youth who already suffer a decrease in this indicator. Kuzmina, Lebedinsky, and Kudryavtsev (2018), Prosvirina, Kolokoltsev, Kolchanova, Cieslicka, and Stankiewicz (2015) and Skurikhina et al. (2016) investigate the issue of organizing educational process in groups with special health needs. Kuzmin, Kopylov, Kudryavtsev, Galimov, and Iermakov (2015) research the issue concerning students who lack physical fitness. Adyrkhaev (2016) works on the methods of physical education improvement for disabled students. Kashuba, Kolos, Rudnytskyi, Yaremenko, Shandrygos, Dudko, and Andrieieva (2017) substantiated the technology of the female students' body state improvement with the use of wellness fitness means.

The problem of weight control is also addressed by a group of scholars: Osipov, Kudryavtsev, Gruzinky, Kramida, and Iermakov (2017) point out the issue of obesity prevention, whereas Kolokoltsev, Iermakov, and Jagiello (2018) study underweight health risks.

Thus, the undertaken analysis of academic literature proves the topicality of the problem stated and conditions the necessity of doing a complex research into youth's physical fitness and morphofunctional state.

The purpose of this research paper is to identify the level of physical fitness and morphofunctional state among the female first-year students at SHEI "Prydniprovska State Academy of Civil Engineering and Architecture".

\section{Materials and methods}

\section{Participants of the research}

The study involved 100 female first-year students of general group aged 17-18, all after medical examination and obtaining doctor's approval: the age group was 18 years old $(n=100)$. All students gave permission to process their personal data.

Organization of the research: to meet the goals set, the following research methods were used: theoretical analysis and generalization of data in specialized scientific and methodological literature, pedagogical testing, anthropometric research methods, functional methods of cardiorespiratory system investigation and methods of mathematical statistics for processing the results of the research.

The investigation into the girls' anthropometric indicators was conducted by comparing them with the average indicators within their gender and age group. Their body length, weight and girth body dimensions were studied, which were measured with a rubber-modified tape measure to within $0.5 \mathrm{~cm}$ (the length of the tape was calibrated according to a metal standard mould after every $20^{\text {th }}$ measuring).

Moreton and Morley (2011) and Shulga (2019) justify the need for assessing students' physical fitness using the index method.

The body mass index (BMI), which is used to assess the correspondence between person's weight and height, is calculated by formula (1).

$$
B M I\left(\frac{k g}{m^{2}}\right)=\frac{m(k g)}{L(m)^{2}} ;
$$

where $m$ is body weight; $L$ is body length.

According to the World Health Organization, the BMI scale is as follows: normal body weight corresponds to BMI indicator between 18.5 and 24.99; indicators of 16-18.4 mean that a person is underweight; figures $25-30$ show that a person is overweight; BMI of more than 30 indicates obesity.

To assess the proportionality and the correspondence of particular segments with the basic anthropometric parameters, the proportionality index (PI) was calculated by dividing the values of different parts of the body girth measurements $(\mathrm{cm})$ by the body length figures $(\mathrm{cm})$ and comparing them to actual and guideline values, provided in table 3 .

Tests and standards, which are used during the annual assessment of Ukrainians' physical fitness level, were included 
Table 1. Guidelines on assessment of Ukrainians' physical fitness level ${ }^{\star}$

\begin{tabular}{|c|c|c|c|c|c|c|}
\hline \multirow[t]{3}{*}{ No. } & \multirow{3}{*}{ The corresponding mark } & \multicolumn{5}{|c|}{ Fitness level } \\
\hline & & high & sufficient & average & low & poor \\
\hline & & 5 & 4 & 3 & 2 & $\mathbf{0}$ \\
\hline 1 & Steady running $2000 \mathrm{~m}$, min. & $\leq 10.3$ & 11.15 & 11.5 & 12.3 & $\geq 12.4$ \\
\hline \multirow[t]{2}{*}{2} & Push-ups, times & $\geq 25$ & $21-24$ & $18-20$ & $15-17$ & $\leq 14$ \\
\hline & or long standing jump, $\mathrm{cm}$ & $\geq 210$ & $200-209$ & $185-199$ & $165-184$ & $\leq 164$ \\
\hline 3 & Sprint $100 \mathrm{M}, \mathrm{C}$ & $\leq 14.8$ & $14.9-15.5$ & $15.6-16.3$ & $16.4-17.0$ & $\geq 17.1$ \\
\hline 4 & Shuttle running $4 \times 9 \mathrm{~m}$, sec & $\leq 10.4$ & $10.5-10.8$ & $10.9-11.3$ & $11.4-11.6$ & $\geq 11.7$ \\
\hline 5 & Forward bend from a seated position, $\mathrm{cm}$ & $\geq 20$ & $18-19$ & $16-17$ & $9-15$ & $\leq 8$ \\
\hline- & Total score & $21-25$ & $16-20$ & $11-15$ & $6-10$ & $0-5$ \\
\hline
\end{tabular}

Note: ${ }^{\star}$ - for girls aged $18-22$

into the scheme of testing to assess physical fitness levels (Prontenko, Griban, Medvedeva, Aloshyna, Bloshchynskyi, Bezpaliy, Bychuk, Mudryk, Bychuk, Radziyevsky, Filatova, \& Yevtushok, 2019). The criterea of these tests are stated in Table 1.

The corresponding number of points was awarded for each of the results. In the end, the scores for each of the tests were summed. The assessment of the physical fitness level was carried out depending on the total number of points.

Such cardiorespiratory indicators as heart rate (HR), systolic and diastolic blood pressure (SBP and DBP respectively) and respiratory rate (RR) were measured at rest according to standard methods in order to assess the functional state of the students. Yarmak et al. (2017) and Kozhokar, Vaskan, Palagniuk, Zavgorodnia, Strazhnikova, Kyselytsia, Balatska, and Yarmak (2019) recommend using such tests, based on breath holding to determine the resistance to hypoxia, as Shtange and Genchi timed inspiratory capacity tests, performed according to standard methods. Standard heart rate for a healthy person at rest is $60-80$ beats per minute, SBP is between 100 and $120 \mathrm{mmHg}$; $\mathrm{DBP}$ is between 60 and 80 $\mathrm{mmHg}$; $\mathrm{RR}$ at rest is $16-18$ respiratory acts per minute, the result of the Shtange test for untrained people is $40-50$ seconds, the Genchi test is 25-30 seconds.

The Rufier cardiovascular endurance test, which was also performed in compliance with standard methods, allows to assess workability (capability to endure dynamic load). Before the test starts, the subject is given an opportunity to rest: they sit still for 5 minutes. Then their pulse is taken for 15 seconds (P1). Afterwards 30 deep squats are done within 45 seconds. Immediately after the load the pulse is taken again in the standing position for 15 seconds (P2). After the first minute of recovery the pulse is taken again in the sitting position for 15 seconds (P3). The Rufier index is calculated by formula (2): Rufier index $=\left(4^{*}(P 1+P 2+P 3)-200\right) / 10 \quad$ (2);

the results were evaluated by the index guidelines: less than 3 means excellent performance; 4-6 means good performance; 7-9 is average performance; 10-14 is satisfactory performance, and above 15 is poor performance.

Additional indicators showing circulatory system performance were calculated for a more detailed study of physical fitness levels:

Circulation efficiency factor (CEF) was calculated by formula (3): $C E F=(S B P-D B P){ }^{*} H R$ normally the factor is $2400-2600$ conventional units; it can increase because of fatigue, overexertion or overtraining.

Furthermore, adaptive potential (AP), which was introduced by R. M. Baevsky in order to predict prenozology within a mass screening, was assessed to determine female students' adaptive capacity. The level of adaptive potential is determined by formula (4):

$A P=0,011^{\star} H R+0.014^{\star} S B P+0.008^{\star} D B P+0.009^{\star} M+0.001$

$4^{\star} A-0.009^{\star} L-0.27$,

where $M$ is body weight (in k)g; $A$ is age( in years); $L$ is body length (in $\mathrm{cm}$ ).

The adaptive potential points can be interpreted as follows: figures under 2.1 indicate sufficient adaptive potential; the score of 2.11-3.2 demonstrates some strain of adaptation mechanisms; the total of points between 3.21 and 4.3 reflects insufficient adaptation; the result less than 4.31 reflects adaptation failure.

In order to evaluate myocardium metabolic and energy processes, the Robinson's Index, which characterizes cardiovascular system regulation and is determined by formula (5), was used.

The Robinson's Index $=(H R * S B P) / 100$ (5).

Myocardium metabolic and energy processes can be interpreted relative to the Robinson's index as follows: the index of less than 69 demonstrates high level of energy metabolism, the rate of 70-84 is higher than average, the score 85-94 indicates an average level of processes, 95-110 points show lower than average rates, the total of more than 111 reflects poor myocardium energy metabolism.

\section{Statistical analysis}

The results obtained were processed using descriptive statistics of the licensed Excel package. In order to analyze the sample for each variable, the mean value $(\mathrm{X})$, the mean error $(\mathrm{m})$, standard deviation (S) and the coefficient of variation (V) were determined. In order to statistically test the hypothesis regarding the reliability of the differences, the Student's T-test was applied.

\section{Results}

The results of studying the main anthropometric characteristics in comparison with the benchmarks of physical 
Table 2. The main anthropometric indicators among firstyear female students $(n=100)$

\begin{tabular}{lcccc}
\hline $\begin{array}{c}\text { Anthropometric } \\
\text { indicators }\end{array}$ & $\mathbf{X}$ & $\mathbf{S}$ & $\mathbf{V}$ & $\begin{array}{c}\text { Average } \\
\text { parmeters of } \\
\text { physical fitness } \\
\text { level for girls } \\
\text { aged 18* }\end{array}$ \\
\hline Body length, cm & 166.6 & 5.332 & 3.2 & $160.4-167.0$ \\
$\begin{array}{l}\text { Body weight, kg } \\
\begin{array}{l}\text { Chest } \\
\text { circumference, cm }\end{array}\end{array}$ & 58.12 & 8.669 & 14.92 & $56.5-65.3$ \\
\hline
\end{tabular}

Note: ${ }^{\star}$ - according to the assessment of physical fitness with the population of central (Kuts, 1993).

Table 3. Anthropometric indicators of first-year students $(\mathrm{n}=100)$

\begin{tabular}{|c|c|c|c|c|c|c|c|}
\hline \multirow[t]{2}{*}{ Indices, CU } & \multirow[t]{2}{*}{$\mathrm{X}$} & \multirow[t]{2}{*}{$\mathbf{S}$} & \multirow[t]{2}{*}{ V } & \multirow{2}{*}{$\begin{array}{l}\text { Guideline } \\
\text { intervals }\end{array}$} & \multicolumn{3}{|c|}{$\begin{array}{l}\text { Number of } \\
\text { students, \% }\end{array}$} \\
\hline & & & & & $<\mathrm{N}$ & $\mathbf{N}^{*}$ & $>\mathrm{N}$ \\
\hline BMI & 20.932 & 2.852 & 13.62 & $18.5-24.99$ & 18 & 76 & 6 \\
\hline Chest & 0.507 & 0.032 & 6.39 & 05 & 2 & 93 & 5 \\
\hline Waist PI & 0.402 & 0.040 & 9.90 & 0.35 & 4 & 83 & 13 \\
\hline Pelvis PI & 0.582 & 0.041 & 7.08 & $0.54-0.62$ & 11 & 72 & 17 \\
\hline Thigh PI & 0.340 & 0.030 & 8.76 & $0.32-0.36$ & 17 & 62 & 21 \\
\hline Shin PI & & 0.017 & 7.92 & $0.21-0.23$ & 25 & 63 & 12 \\
\hline Shoulder PI & 0.162 & 0.026 & 16.24 & $0.16-0.18$ & 42 & 48 & 10 \\
\hline
\end{tabular}

Note: $\mathrm{N}^{\star}-\mathrm{N}$ - indicators within the norm

fitness with the population of central Ukraine are presented in table 2 .

The study of the variation coefficient for anthropometric parameters and indices revealed their insignificant and average variability (Table $2-3$ )

Thus, $76 \%$ of students had normal body weight, $18 \%$ of respondents were underweight, and only $6 \%$ of surveyed female students were overweight. The evaluation of the students' body dimensions proportionality according to the corresponding indices revealed a minor downward variation of the shin PI and shoulder PI indicators, as well as the upward variation of the waist PI and pelvis PI.

The study of students' physical fitness level revealed a predominantly low level of physical fitness among girls according to all the indicators, except the results of such tests as shuttle running and forward bend from a seated position (Table 4).

Thus, according to the results of such tests as steady running for 2000 meters, long standing jump and sprint for 100 meters, about $80 \%$ of the girls have low physical fitness level $(83 \%, 82 \%$ and $80 \%$ respectively). The investigation into the sample variation revealed a low level of variability for the results of such tests as shuttle running and sprint $100 \mathrm{~m}$, such tests as steady running $2000 \mathrm{~m}$ and long standing jump showed the average variability, whereas the variability for such tests as push-ups and forward bend from a seated position was high.

The results of statistical verification of the hypothesis concerning the credibility of the diversity of the physical fitness level indicators, which were calculated using different tests clusters, are presented in Table 5.

The study of variability indicators for functional state revealed the high level of variability for functional tests and $\mathrm{CEF}$, as well as the average level of variability for HR and RR at rest, the indices of blood pressure, AP and the Robinson's index (Table 6).

The investigation of respiratory system among female students revealed the excess of RR at rest (with $29 \%$ of girls) as well as the decrease in the Stange test (46\%) and the Genchi test (49\%). Among the cardiovascular system indicators the excess was noted for such indices as CEF (55\% of students), and HR at rest (36\% of students). According to the Rufier index, only $1 \%$ of girls have excellent performance; good performance was noted only with $12 \%$ of girls; $16 \%$ showed average performance; satisfactory performance was revealed with $37 \%$ of the girls investigated, and poor performance was registered with $34 \%$ of students. The indicators of BP (blood pressure), the adaptation to the physical load according to $\mathrm{AP}$ and the processes of energy exchange in myocardium according to the Robinson's index, were satisfactory with most investigated students.

Table 4. The indicators of physical fitness among first-year students $(n=100)$

\begin{tabular}{|c|c|c|c|c|c|c|c|c|}
\hline \multirow{2}{*}{ Tests } & \multirow{2}{*}{$\mathbf{X}$} & \multirow{2}{*}{$S$} & \multirow{2}{*}{$\mathbf{V}$} & \multicolumn{5}{|c|}{ Number of students, \% } \\
\hline & & & & high & sufficient & average & low & poor \\
\hline Steady running $2000 \mathrm{~m}$. & 13.356 & 1.594 & 11.93 & 3 & 3 & 11 & 12 & 71 \\
\hline Push-ups & 13.55 & 6.844 & 50.51 & 10 & 3 & 19 & 14 & 54 \\
\hline Long standing jump & 168.65 & 17.633 & 10.46 & - & 6 & 12 & 50 & 32 \\
\hline Sprint $100 \mathrm{~m}$. & 17.175 & 1.073 & 6.25 & 2 & 5 & 13 & 25 & 55 \\
\hline Shuttle running $4 \times 9 \mathrm{~m}$. & 10.508 & 0.521 & 4.96 & 50 & 32 & 9 & 6 & 3 \\
\hline Forward bend from a seated position & 16.02 & 7.015 & 43.79 & 33 & 19 & 12 & 17 & 19 \\
\hline Fitness level $^{*}$ & 11.58 & 3.856 & 33.30 & 2 & 15 & 47 & 31 & 5 \\
\hline Fitness level ${ }^{\star \star}$ & 11.98 & 3.875 & 32.53 & 2 & 18 & 44 & 31 & 5 \\
\hline
\end{tabular}

Note: $\quad *$ - by the sum of points taking into account the result of long standing jump

** - by the sum of points taking into account the result of push-up test 
Table 5. The comparison of physical fitness level indicators, calculated using different tests clusters

\begin{tabular}{llllllll}
\hline $\begin{array}{l}\text { The physical fitness level calculated } \\
\text { considering test results: }\end{array}$ & $\begin{array}{l}\text { The results } \\
\text { of statistical } \\
\text { comparison }\end{array}$ \\
\hline Long standing jump & \multicolumn{2}{l}{ Push-ups } \\
\hline$X_{1}$ & $\boldsymbol{m}_{1}$ & $S_{1}$ & $X_{1}$ & $m_{1}$ & $S_{1}$ & t calc. \\
\hline 11.58 & 0.386 & 3.857 & 11.91 & 0.388 & 3.875 & $0.604^{*}$ \\
\hline
\end{tabular}

Note: ${ }^{*}$ the discrepancy between the samples is unreliable,

because $t$ calc. $<\mathrm{t}$ of the criterion $(\mathrm{p}=0.001)$

Table 6. Assessment of first-year students' functional state of $(\mathrm{n}=100)$

\begin{tabular}{lcccccccc}
\hline \multicolumn{1}{c}{ Indices } & $\mathbf{X}$ & $\mathbf{S}$ & $\mathbf{V}$ & $\begin{array}{c}\text { Normative } \\
\text { intervals }\end{array}$ & \multicolumn{3}{c}{$\begin{array}{c}\text { Number of } \\
\text { students, \% }\end{array}$} \\
\cline { 6 - 9 } & & & & & $<\mathbf{N}$ & $\mathbf{N}$ & $>\mathbf{N}$ \\
\hline $\begin{array}{l}\text { HR at rest, } \\
\text { bpm }\end{array}$ & 78.61 & 13.82 & 17.58 & $60-80$ & 1 & 63 & 36 \\
SBP, mmHg & 107.66 & 11.08 & 10.29 & $100-120$ & - & 98 & 2 \\
DBP, mmHg & 71 & 7.61 & 10.72 & $60-80$ & - & 98 & 2 \\
$\begin{array}{l}\text { RR at rest, } \\
\text { times }\end{array}$ & 16.9 & 4.10 & 24.22 & $16-18$ & 34 & 37 & 29 \\
$\begin{array}{l}\text { The Shtange } \\
\text { test, sec }\end{array}$ & 43.68 & 13.71 & 31.39 & $40-50$ & 46 & 27 & $27^{*}$ \\
$\begin{array}{l}\text { The Genchi } \\
\text { test, sec }\end{array}$ & 26.74 & 11.092 & 41.48 & $25-30$ & 49 & 24 & $27^{*}$ \\
$\begin{array}{l}\text { The Rufier } \\
\text { index, CU }\end{array}$ & 12.725 & 5.317 & 41.78 & $0-14$ & - & 66 & 34 \\
CEF, CU & 2896.88 & 823.74 & 28.44 & $2400-2600$ & $31^{*}$ & 14 & 55 \\
$\begin{array}{l}\text { AP, CU } \\
\text { The }\end{array}$ & 1.718 & 0.30 & 17.50 & $<2,11$ & - & 89 & 11 \\
$\begin{array}{l}\text { Robinson's } \\
\text { index, CU }\end{array}$ & 85.076 & 19.70 & 23.16 & $<111$ & - & 88 & 12 \\
\hline
\end{tabular}

Note: ${ }^{\star}$ - the value of the indicator is better than the norm

\section{Discussion}

According to the results of comparison of the body length, body weight and chest circumference indicators among female first-year students in Prydniprovska State Academy of Civil Engineering and Architecture with the standard indicators within their gender and age group, the investigated students have the average level of physical fitness (see Table 2). The correction of the minor insufficiency with the girths (see Table 3 ) of the shoulder ( $42 \%$ of the girls investigated) and shin (25\%) is possible with the implementation of strength exercises with the aim of increasing the girths by increasing the circumference of the corresponding muscle groups.

In the course of the research, there were confirmed the findings by Maslyak and Krivoruchko (2016), Kozhokar et al. (2019), Lebedinskiy, Koipysheva, Rybina, Kudryavtsev, Iermakov, Osipov, and Sidorov (2017), and Yarmak et al. (2017) concerning the indices of body length and weight; by Tsybul'ska (2014), Druz, Iermakov, Nosko, Shesterova, and Novitskaya (2017) and Kozhokar, Kurnyshev, Palichuk, Balatska, and Yarmak (2018) concerning the girths of waist and pelvis; by Yarmak, Buhaienko, Zhukov, Cherniakova, Vorona, Bilenkova, and Blagii (2019) and Kashuba et al. (2017) concerning the BMI.
According to the results of running for 2000 meters, sprint for 100 meters and the push-up tests, 71\%, 54\% and $55 \%$ of girls (respectively) were not able to meet even the standard approved for low fitness level (see Table 4). Students' poor physical fitness test results condition using the means and methods aimed at the development of speed and strength endurance and the upper limbs strength in further activities for students showing low physical fitness levels as well as the implementation of additional self-training, aimed at the development of the corresponding physical features. Besides, the high level of variability for such indices as the strength of the upper limbs and flexibility demonstrates the necessity to divide the girls into subgroups while developing the corresponding physical features or the necessity for them to attend additional PE classes of various types. The conducted studies of female students' physical fitness confirmed and supplemented the findings by Osipov, Kudryavtsev, Iermakov, Yanova, Lepilina, Plotnikova, and Dorzhieva (2017), Kashuba et al. (2017) and Fotynyuk (2017).

The statistical verification of the hypothesis on the reliability of differences between the values of physical fitness indicators, determined by the sum of points scored on the results of 5 tests, taking into account the long steady jump test or the push-ups test, confirmed the feasibility of complementing the physical exercises, selected to determine the level of physical fitness among female students (see Table 5).

The study of functional state revealed insufficient resistance to hypoxia with a significant number of girls tested, as well as variations from the standard indices of the cardiorespiratory system (see Table 6). Thus, according to the results of the Shtange and the Genchi tests, the reduced indicators were revealed with $46 \%$ and $49 \%$ of the girls investigated, respectively. The excess of CEF was observed with $55 \%$ of students, and the excess of heart rate and RR at rest was found with $36 \%$ and $29 \%$, respectively. According to the Rufier test results, the reduced indicators were observed with $71 \%$ of girls investigated. The decreased indices of the cardiorespiratory system performance and workability necessitate the use of additional breathing exercises and the exercises aimed at developing endurance.

At the course of these studies of female students' functional state there were confirmed the findings by Maslyak et al. (2016), Kozhokar et al. (2019) regarding blood pressure; as well as the findings by Kozhokar et al. (2019) and Fotynyuk (2017) regarding the Rufier index; the findings by Druz et al. (2017) and Kozhokar et al. (2018) concerning the Robinson's index; as well as the findings by Yarmak et al. (2017) and Kozhokar et al. (2019) concerning the Genchi test.

According to the study, the functional characteristics of most students tested are on the border between the norm and pathology, which justifies the need to prevent their further deterioration by increasing the amount of physical activity through the introduction of new forms of training and improving the students' physical fitness level by means of physical education.

Thus, despite the fact that the anthropometric characteristics of the investigated girls are mostly within the norm, most female students have reduced physical fitness levels in terms of speed and strength endurance, explosive physical force of the lower limbs and strength endurance of the upper limbs, which confirms the findings of other studies. The low level of physical fitness, as well as reduced indicators of the functional state among the tested students necessitate 
the improvement of the system of physical education at the technical higher education institution. The high variability of physical fitness indicators requires obligatory taking into consideration the students' individual characteristics during the selection of exercises and calculation of training load.

\section{Conclusions}

The study revealed the low level of physical fitness among the investigated students in terms of speed and strength endurance indicators ( $83 \%$ according to the 2000 meters running test and $80 \%$ according to the 100 meters running test), explosive physical force of the lower limbs ( $82 \%$ for the results of the long steady jump test) and strength endurance of the upper limbs (68\% according to the push-ups test), as well as reduced functional characteristics: resistance to hypoxia (according to the results of the Shtange test with $46 \%$ and the Gench's test with $49 \%$ ), workability ( $71 \%$ according to the results of the Rufier test) and efficiency of cardiovascular system (55\% according to the circulation efficiency factor). Low physical fitness levels among the tested girls necessitate the additional introduction of more intensive training, and the reduced cardiorespiratory system performance and workability condition the need to use breathing exercises and exercises aimed at developing endurance. The high variability of the physical fitness indicators among the students requires personalization of the training process, as well as the obligatory use of express testing methods for the physical state of each student during a workout, especially during exercising at maximum capacity.

Prospects for further research: improving the system of physical education in Prydniprovska State Academy of Civil Engineering and Architecture in connection with the low level of physical fitness among first-year students.

\section{Conflict of interest}

The authors declare no conflict of interest.

\section{References}

Adyrkhaev, S. G. (2016). Modern technology of physical education of disabled students in conditions of inclusive education. Pedagogics, psychology, medical-biological problems of physical training and sports, 20(1), 4-12. https://doi.org/10.15561/18189172.2016.0101

Aghyppo, A., Tkachov, S., \& Orlenko, O. (2016). Role of physical education on the formation of a healthy lifestyle outside of school hours. Journal of Physical Education and Sport, 16(2), Art 54, 335-339.

https://doi.org/10.7752/jpes.2016.02054

Anikieiev, D. M. (2015). Criteria of effectiveness of students' physical education system in higher educational establishments. Physical education of students, 19(5), 3-8. https://doi.org/10.15561/20755279.2015.0501

Bondarenko, I. H., Dzyuban, O. V., Isayenko, M. V., \& Bondarenko O. V. (2018). The results of the annual assessment of the physical preparedness of students. Visnyk Chernihivskoho natsionalnoho pedahohichnoho universytet, pedahohichni nauky, 152(2), 40-44. (in Ukrainian)

Butenko, G., Goncharova, N., Saienko, V., \& Tolchieva, H. (2017) Use of health tourism as a basis for improving physical condition of primary school age children. Journal of Physical Education and Sport (JPES), 17(6), 34-39. http://reposit.uni-sport.edu.ua/handle/787878787/1958

Gryban, G. (2014). Background for creation of methodical system of physical education of students in higher educational institutions. Slobozhanskyi naukovosportyvnyi visnyk, 2(40), 67-71. https://doi.org/10.15391/snsv.2014-2.013 (in Ukrainian)

Druz, V., Iermakov, S., Nosko, M., Shesterova, L., \& Novitskaya, N. (2017). The problems of students' physical training individualization. Pedagogics, Psychology, MedicalBiological Problems of Physical Training and Sports, 21(2), 51-59. https://doi.org/10.15561/18189172.2017.0201

Fotynyuk, V. G. (2017). Determination of first year students' physical condition and physical fitness level. Physical education of students, 21(3), 116-120. https://doi.org/10.15561/20755279.2017.0303

Jaakkola, T., Yli-Piipari, S., Barkoukis, V., \& Liukkonen, J. (2017). Relationships among perceived motivational climate, motivational regulations, enjoyment, and PA participation among Finnish physical education students. International Journal of Sport and Exercise Psychology, 15(3), 273-290. https://doi.org/10.1080/1612197X.2015.1100209

Kashuba, V., Asaulyuk, I., \& Diachenko, A. (2019). Dynamics of core muscles' static strength endurance of students of higher education establishments in physical training process. Naukovyi chasopys NPU im. M. P. Drahomanova. Naukovo-pedahohichni problemy fizychnoi kultury (fizychna kultura $i$ sport), 7(115), 47-51. http://enpuir.npu. edu.ua/handle/123456789/26722 (in Ukrainian)

Kashuba, V., Kolos, M., Rudnytskyi, O., Yaremenko, V., Shandrygos, V., Dudko, M., \& Andrieieva, O. (2017). Modern approaches to improving body constitution of female students within physical education classes. Journal of Physical Education and Sport, 17(4), 2472-2476. https://doi.org/10.7752/jpes.2017.04277

Kolokoltsev, M. M., Iermakov, S. S., \& Jagiello, M. (2018). Physical condition of female students with different level of body mass deficiency. Physical education of students, 22(2), 63-69. https://doi.org/10.15561/20755279.2018.0202

Kozhokar, M., Kurnyshev, Y., Palichuk, Y., Balatska, L., \& Yarmak, O. (2018). Monitoring of the physical fitness of 17-19 year old young men during physical education. Journal of Physical Education and Sport, 18(286), 19391944. https://doi.org/10.7752/jpes.2018.s4286

Kozhokar, M., Vaskan, I., Palagniuk, T., Zavgorodnia, T., Strazhnikova, I., Kyselytsia, O., Balatska, L., \& Yarmak, Y. (2019). The complex effects of health-improving fitness on the physical condition of students. Journal of Physical Education and Sport, 19(s6), 2133-2138. https://doi.org/10.7752/jpes.2019.s6320

Kozina, Z. L., Ol'khovyj, O. M., \& Temchenko, V. A. (2016). Influence of information technologies on technical fitness of students in sport-oriented physical education. Physical education of students, 20(1), 21-28. https://doi.org/10.15561/20755279.2016.0103

Kuts, A. S. (1993). Modelnye pokazately fyzycheskoho razvytyia y dvyhatelnoi podhotovlennosty naselenyia Tsentralnoi Ukrayni [Model indicators of physical development and physical fitness of the population of Central Ukraine]. Kyiv: Yskra, 256. (in Russian)

Kuzmin, V. A., Kopylov, Y. A., Kudryavtsev, M. D., Galimov, G. Y., \& Iermakov, S.S. (2015). Substantiation of effectiveness of trainings on health related methodic for students with 
weakened motor fitness. Physical education of students, 6 , 43-49. http://dx.doi.org/10.15561/20755279.2015.0606

Kuzmina, O. I., Lebedinsky, V. Y., \& Kudryavtsev, M. D. (2018). Monitoring of students' health of function group III in technical institutions. The European Proceedings of Social \& Behavioural Sciences EpSBS, 683-687.

https://doi.org/10.15405/epsbs.2018.12.84

Lebedinskiy, V. Y., Koipysheva, E. A., Rybina, L. D., Kudryavtsev, M. D., Iermakov, S. S., Osipov, A. Y., \& Sidorov, L. K. (2017). Age dynamic of physical condition changes in pre-school age girls, schoolgirls and students, living in conditions of Eastern Siberia. Physical education of students, 21(6), 280-286.

https://doi.org/10.15561/20755279.2017.0604

Malimon, O., Pantik, V., \& Tsos, A. (2018). Differentiated approach to students physical education of higher education institutions. Visnyk Chernihivskoho natsionalnoho pedahohichnoho universytet, pedahohichni nauky, 151(1), 99-104. (in Ukrainian)

Maslyak, I. P., \& Krivoruchko, N. V. (2016). Physical development of students of teacher training college as a result of exercises of cheerleading. Physical education of students, 20(1), 55-63.

https://doi.org/10.15561/20755279.2016.0108

Moreton, R., \& Morley, J. (2011). Investigation into the use of photoanthropometry in facial image comparison. Forensic science international, 212(1-3), 231-237. https://doi.org/10.1016/j.forsciint.2011.06.023

Moskalenko, N., \& Pichurin, V. (2017). Analiz fizychnoi pidhotovlenosti studentok. Sportyvnyi visnyk Prydniprovia, 3, 97-100. (in Ukrainian)

Nagovitsyn, R., Osipov, A., Manurov, I., Zhuikov, R., \& Vershinina, N. (2019). Adaptation of foreign female students to physical activity based on the dexterity development. Physical education of students, 23(2), 70-4. https://doi.org/10.15561/20755279.2019.0203

Osipov, V. M., \& Budnyi, O. M. (2017). Fizychnyi stan hotovnosti studentiv do testuvannia fizychnykh yakostei za prohramoiu shchorichnoho otsiniuvannia fizychnoi pidhotovlenosti naselennia Ukrainy. Naukovi zapysky Berdianskoho derzhavnoho pedahohichnoho universytetu. Pedahohichni nauky, 2, 279-283. (in Ukrainian)

Osipov, A. Y., Kudryavtsev, M. D., Gruzinky, V. I., Kramida, I. E., \& Iermakov, S. S. (2017). Means of optimal body mass control and obesity prophylaxis among students. Physical education of students, 21(1), 40-45.

https://doi.org/10.15561/20755279.2017.0107

Osipov, A. Y., Kudryavtsev, M. D., Iermakov, S. S., Yanova, M. G., Lepilina, T. V., Plotnikova, I. I., \& Dorzhieva, O. S. (2017). Comparative analysis of effectiveness of some students' physical culture training methodic. Physical education of students, 21(4), 176-181. https://doi.org/10.15561/20755279.2017.0405

Osipov, A., Vonog, V., Prokhorova, O., \& Zhavner, T. (2016). Student learning in physical education in Russia (problems and development perspectives). Journal of Physical Education and Sport, 16(s1), 688-693. https://doi.org/10.7752/jpes.2016.s1111

Paliienko, O. A. (2017). Analiz i shliakhy vyrishennia problem ekolohichnoi bezpeky v Ukraini. Mekhanikotekhnolohichni systemy ta kompleksy. Visnyk NTU KhPI, 19(1241), 147-151. http://repository.kpi.kharkov.ua/ handle/KhPI-Press/30894 (in Ukrainian)

Prontenko, K., Griban, G., Medvedeva, I., Aloshyna, A., Bloshchynskyi, I., Bezpaliy, S., Bychuk, O., Mudryk, Z.,
Bychuk, I., Radziyevsky, V., Filatova, Z., \& Yevtushok, M. (2019). Interrelation of students' motivation for physical education and their physical fitness level. International Journal of Applied Exercise Physiology, 8(2.1), 815-824. https://doi.org/10.30472/ijaep.v8i2.1.566

Prosvirina, L. N., Kolokoltsev, M. M., Kolchanova, M. A., Cieslicka, M., \& Stankiewicz, B. (2015). The characteristic of the engine qualities of the students of technical institute of III functional health group (special medical group). Physical education of students, 19(1), 43-49. https://doi.org/10.15561/20755279.2015.0107

Prusik, K., Prusik, K., Iermakov, S. S., \& Kozina, Z. L. (2012). Indexes of physical development, physical preparedness and functional state of polish students. Pedagogika, psihologia ta mediko-biologicni problemi fizicnogo vihovanna i sportu, 12, 113-122. https://doi.org/10.6084/m9.figshare.105467

Puzdymir, M. (2019). Development of experience, speed and personality by leadership methods of students. Molodyi vchenyi, 3(2), 255-258.

https://doi.org/10.32839/2304-5809/2019-3-67-53 (in Ukrainian)

Shulga, M. (2019). The impact of Mind \& Body on the physical condition of the students. Naukovyi chasopys NPU im. M. P. Drahomanova. Naukovo-pedahohichni problemy fizychnoi kultury (fizychna kultura i sport), 3K(110), 608-612. http:// enpuir.npu.edu.ua/handle/123456789/26962 (in Ukrainian)

Skurikhina, N. V., Kudryavtsev, M. D., Kuzmin, V. A., \& Iermakov, S. S. (2016). Fitness yoga as modern technology of special health groups' girl students' psycho-physical condition and psycho-social health strengthening. Physical education of students, 20(2), 24-31. https://doi.org/10.15561/20755279.2016.0204

Sulz, L., Temple, V., \& Gibbons, S. (2016). Measuring student motivation in high school physical education: Development and validation of two self-report questionnaires. Physical Educator, 73(3), 530-554. https://doi.org/10.18666/TPE-2016-V73-I3-6370

Trotska, M. V., Homlia, I. A., \& Kovalenko, O. O. (2018). Environmental security as a component of the national security of Ukraine through the prism of international experience. Molodyi vchenyi, 10(1), 248-251. (in Ukrainian)

Tsybul'ska, V. V. (2014). Self-appraisal adequacy of students' physical abilities of pedagogical specialties involved in various forms of education. Physical education of students, 18(5), 48-52. https://doi.org/10.15561/20755279.2014.0509

Vaskevich, S. (2019). Modern approaches to development of endurance of students on employments on physical education of univers. Molodyi vchenyi, 2(2), 337-339. (in Ukraine)

Yarmak, O., Galan, Y., Hakman, A., Dotsyuk, L., \& Blagii, O. (2017). The use of modern means of health improving fitness during the process of physical education of student youth. Journal of Physical Education and Sport, 17(3), 1935-1940. https://doi.org/10.7752/jpes.2017.03189

Yarmak, O., Buhaienko, T., Zhukov, O., Cherniakova, Z., Vorona, V., Bilenkova, L., \& Blagii, O. (2019). Specificity of the relationship between the volume of physical activity and the physical condition of 18-19-year-old girls. Journal of Physical Education and Sport, 19(3), 1550-1555. https://doi.org/10.7752/jpes.2019.03224

Zhamardiy, V., Shkola, O., Tolchieva, H., \& Saienko, V. (2020). Fitness technologies in the system of physical qualities development by young students. Journal of Physical Education \& Sport, 20(1), 142-149. https://doi.org/10.7752/jpes.2020.01019 


\title{
АНАЛІЗ ФІЗИЧНОї ПІДГОТОВЛЕНОСТІ ТА МОРФО- ФУНКЦІОНАЛЬНОГО СТАНУ СТУДЕНТОК ПЕРШОГО КУРСУ ЗАКЛАДУ ВИЩОЇ ОСВІТИ ТЕХНІЧНОГО ПРОФІЛЮ
}

\author{
Світлана Сологубова ${ }^{1 \mathrm{ABCDE}}$, Олена Лахно ${ }^{1 \mathrm{ABCDE}}$, Володимир Шиян ${ }^{1 \mathrm{ABCDE}}$, Ольга Шиян ${ }^{1 \mathrm{ABCDE}}$ \\ ${ }^{1}$ Придніпровська державна академія будівництва та архітектури
}

Авторський вклад: А - дизайн дослідження; В - збір даних; C - статаналіз; D - підготовка рукопису; Е - збір коштів

Реферат. Стаття: 8 с., 6 табл., 42 джерела

Мета дослідження - визначити рівень фізичної підготовленості та морфо-функціонального стану студенток першого курсу ДВНЗ ПДАБА.

Матеріали та методи. У дослідженні взяли участь студентки основної групи I курсу ДВНЗ ПДАБА, вік 18 років $(\mathrm{n}=100)$. Для вирішення поставлених завдань було використано: теоретичний аналіз і узагальнення даних спеціальної науково-методичної літератури, педагогічне тестування, антропометричні методи дослідження, функціональні методи дослідження кардіореспіраторної системи та методи математичної статистики обробки результатів дослідження.

Результати. Проведене дослідження підтвердило гіпотезу про необхідність удосконалення системи фізичного виховання у закладі вищої освіти технічного профілю у зв'язку з низьким рівнем фізичного стану студентів.

Висновки. Під час дослідження виявлено низький рівень фізичної підготовленості обстежених студенток за показниками швидкісно-силової витривалості (у 83\%), вибухової сили нижніх кінцівок (у 82\%) та силової витривалості верхніх кінцівок (у 68\%), а також знижені функціональні характеристики: стійкості організму до гіпоксії (за результатами проб Штанге у 46\% та Генчі у $49 \%)$, роботоздатності (у 71\%) та ефективності системи кровообігу (у 55\%). Низька фізична підготовленість обстежених дівчат обумовлює необхідність додаткового впровадження більш інтенсивних форм занять. Велика варіативність показників фізичного стану контингенту вимагає індивідуалізації тренувального процесу, а також обов'язкового використання методів експрес-контролю за фізичним станом кожного студента.

Ключові слова: студентки, фізичне виховання, фізичній стан, функціональні показники, фізична підготовленість.

\section{Information about the authors:}

Solohubova S. V.: sologubova.svitlana@pgasa.dp.ua; https://orcid.org/0000-0002-0374-1686; Department of Physical Education and Sports, State Higher Education Institution "Prydniprovska State Academy of Civil Engineering and Architecture", Chernyshevskoho St, 24-a, Dnipro, 49600, Ukraine.

Lakhno O. G.: lakhno.olena@pgasa.dp.ua; https://orcid.org/0000-0003-1290-6873; Department of Physical Education and Sports, State Higher Education Institution "Prydniprovska State Academy of Civil Engineering and Architecture", Chernyshevskoho St, 24-a, Dnipro, 49600, Ukraine.

Shyyan V. M.: shiyan.volodymyr@pgasa.dp.ua; https://orcid.org/0000-0002-9438-3270; Department of Physical Education and Sports, State Higher Education Institution "Prydniprovska State Academy of Civil Engineering and Architecture", Chernyshevskoho St, 24-a, Dnipro, 49600, Ukraine.

Shyyan O. V.: shiyan.olga@pgasa.dp.ua; https://orcid.org/0000-0002-9989-2939; Department of Physical Education and Sports, State Higher Education Institution "Prydniprovska State Academy of Civil Engineering and Architecture", Chernyshevskoho St, 24-a, Dnipro, 49600, Ukraine.

Cite this article as: Solohubova, S., Lakhno, O., Shyyan, V., \& Shyyan, O. (2020). The Assessment of Physical Fitness and Morphofunctional State of Female First-Year Students in Non-Linguistic Higher Education Institutions. Teorìa ta Metodika Fizičnogo Vihovannâ, 20(3), 157-164. https://doi.org/10.17309/tmfv.2020.3.05

Received: 10.06.2020. Accepted: 20.09.2020. Published: 25.09.2020

This work is licensed under a Creative Commons Attribution 4.0 International License (http://creativecommons.org/licenses/by/4.0). 